\title{
Distribution of TNF- $\alpha$ Among Antenatal Women with Varying Levels of Vitamin D
}

\author{
Bineeta Kashyap ${ }^{1 *}$, Nisha Goyal ${ }^{1}$, Neha Gupta ${ }^{1}$, Sapna Jhanjhria ${ }^{1}$, Mohd Tajuddin ${ }^{2}$, and NP Singh ${ }^{1}$ \\ ${ }^{1}$ Department of Microbiology, University College of Medical Sciences \& Guru Teg Bahadur Hospital, Delhi. \\ ${ }^{2}$ Department of Microbiology, Delhi State Cancer Institute, Delhi
}

\begin{abstract}
Background and Objective: Vitamin D deficiency in antenatal mothers adversely affects not only the health of pregnant mother but also her child. Vitamin D is crucial for proper immune system functioning and management of cytokine environment. Relationship between vitamin D deficiency and TNF- $\alpha$ may prove useful in early detection of inflammatory conditions in pregnant mothers. Therefore, this study assessed serum vitamin D and TNF- $\alpha$ levels in antenatal mothers.

Materials \& Methods: 78 serum samples of healthy pregnant mothers were included. Serum 25-OH Vitamin D and TNF- $\alpha$ levels were estimated using commercially available ELISA kits.

Results: $25-\mathrm{OH}$ Vitamin D levels were inadequate $(<32 \mathrm{ng} / \mathrm{ml})$ in $94.9 \%$ of antenatal cases. Majority $(74.4 \%)$ had an insufficient $(11-32$ $\mathrm{ng} / \mathrm{ml}$ )25-OH Vitamin D level. Mean and median vitamin D levels were $16 \pm 7.5 \mathrm{SD}$ and $14.5 \mathrm{ng} / \mathrm{ml}(3.5-39.5)$ respectively in antenatal mothers. None or a very weak positive linear relationship was observed between serum 25-OH Vitamin D and TNF- $\alpha$ levels (r: 0.13). No correlation was seen between 25-OH Vitamin D \& age and TNF- $\alpha$ \& age (r: 0.04; r: 0.06 respectively).

Conclusions: In settings where subnormal vitamin D levels are prevalent in antenatal mothers, screening for vitamin D deficiency in early pregnancy with subsequent supplementation if needed is recommended. No correlation was observed between serum vitamin $\mathrm{D}$ and proinflammatory marker TNF- $\alpha$ levels. Further elaborate studies are required to investigate the effects of vitamin D on cytokine environment especially in pregnant mothers.
\end{abstract}

Keywords: Vitamin D, 25-OH Vitamin D, TNF- $\alpha$, Antenatal, Cytokine

\section{Introduction}

Vitamin D plays a pivotal role in the maintenance of homeostasis of calcium and phosphate. It makes vitamin D crucial for proper bone mineralization and growth. Pregnancy is associated with enhanced demand of calcium as the maternal body adapts to meet the increasing foetal requirements. Several studies have reported anincreased levels of vitamin D in antenatal and lactating mothers.1-3 This emphasizes the enhanced demand of vitamin D during pregnancy.4 Vitamin D deficiency can result in adverse maternal outcomes, like recurrent abortions, 5 preterm delivery, 6 induced hypertension,7gestational diabetes mellitus. 8

Vitamin D deficiencyin mother enhances the risk of vitamin $\mathrm{D}$ deficiency in neonate. The birth weight of neonates born to vitamin D deficient mothers are reportedly lower than the ones born to mothers having sufficient vitamin D levels.9In foetus it can lead to delay in the ossification of cranial vertex, enlarged cranial fontanelles and impairment in foetal bone ossification.4 Vitamin D deficiency is also a significant cause of neonatal hypocalcaemic seizures.10Deficiency of vitamin D in mother can influence the development of foetus in a more extensive manner. Vitamin D is now also being acknowledged for its several other roles, like immuno-regulation, enhanced insulin secretion.11Vitamin $\mathrm{D}$ has a significantimmune modulatory role. The deficiency of vitamin D enhances the risk of developing infectious diseases and malignancies.12Maternal vitamin D deficiency may also result in asthma in progeny.13Thustimely corrective measures for vitamin D deficiency in antenatal mothers can potentially prevent vitamin $\mathrm{D}$ deficiency and hypocalcaemia in their neonates. 11

Tumor necrosis factor (TNF- $\alpha$ )is primarily produced byactivated macrophages, $\mathrm{T}$ lymphocytes and dendritic cells.14-16TNF- $\alpha$ also acts synergistically with interferon (IFN)- $\gamma$ and enhances theproduction of reactive nitrogen intermediates (RNIs).17, $18 \mathrm{TNF}-\alpha$ plays an important role in the acute phase reaction. It acts by enhancing the inflammatory response to infection. Thus serum TNF- $\alpha$ levels may be used as a marker for an inflammatory infection. This multifaceted cytokine also plays a crucial role in the regulation of ovarian cycle in young women. TNF- $\alpha$ is necessary for the normal growth and development of ovarian follicle.19 It has also been reported that an increased serum levels of TNF- $\alpha$ is related with infertility and recurrent spontaneous abortions. 20 
Although vitamin D deficiency is suspected to be a universal health issue, only fewer countries have the data available for the assessment of vitamin D deficiency in their antenatal population. There is need for the representative data for vitamin D deficiency in antenatal mothers in order to take the necessary steps to prevent the effects of vitamin $\mathrm{D}$ deficiency in the mothers and their neonates. Vitamin D deficiency is associated with enhanced risk of developing infectious diseases in particular tuberculosis (TB), which is endemic in our scenario and accounts for huge morbidity and mortality. The relationship between vitamin $\mathrm{D}$ deficiency and TNF- $\alpha$ may prove to be helpful in early detection of these inflammatory conditions in antenatal mothers.Therefore, in this study we have assessed the serum vitamin D and TNF- $\alpha$ levels in the antenatal mothers.

\section{Materials and Methods}

The present study was carried out in a tertiary care centre of east Delhi. The serum samples of the pregnant mothers availing antenatal care that were receivedin our serology lab for routine Venereal Disease Research Laboratory (VDRL) testing and were found to be non-reactive were included in the study. No additional sample was taken for this study.Only the samples with no pathological condition mentioned or suspected on requisition form were included.78 such antenatal serum samples were collected. The information pertaining to demographic profile was collected from the requisition form.

The collected Serum samples were stored at $-800 \mathrm{C}$ until furtherassayed. The commercially available kits were used for the quantitative determination of total $25-\mathrm{OH}$ Vitamin D and TNFa in antenatal serum. Total 25-OH Vitamin D levels were estimated withCalbiotech: A life science company (Spring Valley, CA) and TNF $\alpha$ levels by Diaclone Human ELISA kit (France). The manufacturer's instructions were thoroughly followed throughout the procedure. The individual manufacturer for $25-\mathrm{OH}$ Vitamin D claims the analytical sensitivity of $2.5 \mathrm{ng} /$ $\mathrm{ml}$ with standard range of $2.5-150 \mathrm{ng} / \mathrm{ml}$. The individual manufacturer for 25-OH Vitamin D claims the analytical sensitivity of $2.5 \mathrm{ng} / \mathrm{ml}$ with standard range of $2.5-150 \mathrm{ng} /$ ml. ForTNF- $\alpha$ sensitivity was less than $8 \mathrm{pg} / \mathrm{ml} .25-\mathrm{OH}$ Vitamin D assay was a solid phase ELISA, based on the principle of competitive binding whereas $\mathrm{TNF} \alpha$ assay was based on the principle of solid phase sandwich ELISA. The levels of both the markers were determined by extrapolating ODvalues against the individual marker's standard concentrations using the standard curve. The antenatal serum 25-OH Vitamin D levels of $<11,11-32$ and $32-100 \mathrm{ng} / \mathrm{mlwere}$ classified as severe deficiency, insufficiency and adequacy respectively.21 The statistical analyses was performed using Microsoft Excel2013.

\section{Results}

The age of cases ranged from 19-31 years with a mean age of 24.3 years. The majority $(69.2 \%)$ of antenatal cases were in 19-25 years age-group. The25-OH Vitamin D levels were inadequate $(<32 \mathrm{ng} / \mathrm{ml})$ in $94.9 \%$ of the antenatal cases included in this study. Majority of cases had aninsufficient (11-32 ng/ml)25-OH Vitamin D levels (figure 1).Table1 shows the age wise distribution of serum $25(\mathrm{OH})$ vitamin $\mathrm{D}$ levels in antenatal cases. The percentage of antenatal cases with severe 25-OH Vitamin D deficiency $(<11 \mathrm{ng} /$ $\mathrm{ml}$ ) was higher in the younger (19-25 years) age group than the older (26-31 years) age group. None of the antenatal mothers in 26-31 years age group had an adequate ( $\geq 32 \mathrm{ng}$ / $\mathrm{ml}$ ) serum level of 25-OH Vitamin D. The mean and median vitamin D levels were $16 \pm 7.5 \mathrm{SD}$ and $14.5 \mathrm{ng} / \mathrm{ml}(3.5-39.5)$ respectively in antenatal mothers. The mean serum levels of $25-\mathrm{OH}$ Vitamin D were $15.4 \mathrm{ng} / \mathrm{ml}$ and $17.6 \mathrm{ng} / \mathrm{ml}$ in 19-25 and 26-31 years age groups respectively (figure 2).

Mean TNF- $\alpha$ level in antenatal mothers was $24.3 \mathrm{pg} / \mathrm{ml}$. The mean TNF $\alpha$ serum levels were $21 \mathrm{pg} / \mathrm{ml}$ and $29.4 \mathrm{pg} / \mathrm{ml}$ in 19-25 and 26-31 years age groups respectively (figure 2). The mean serum TNF- $\alpha$ levels were 14.8, 25.8 and 26.4 in antenatal cases with serum 25-OH Vitamin D levels $<11 \mathrm{ng} / \mathrm{ml}, 11-32 \mathrm{ng} / \mathrm{ml}$ and $\geq 32 \mathrm{ng} / \mathrm{ml}$ respectively.A very weak positive linear or no relationship was seen between the serum 25-OH Vitamin D and TNF- $\alpha$ levels (r: 0.13). The correlation coefficient implied none or a very weak positive linear relationship between $25-\mathrm{OH}$ Vitamin D \& age and TNF- $\alpha$ \& age (r: 0.04; r:0.06 respectively).

Table 1: Age wise distribution of serum 25-(OH) vitamin D levels in antenatal cases $(n=78)$.

\begin{tabular}{|c|c|c|c|}
\hline \multirow[b]{2}{*}{ 25(OH) vitamin D level (ng/ml) } & \multirow[b]{2}{*}{ Number } & \multicolumn{2}{|c|}{ Age group } \\
\hline & & $\begin{array}{c}19-25 \text { years } \\
N(\%)\end{array}$ & $\begin{array}{c}\text { 26-31 years } \\
N(\%)\end{array}$ \\
\hline$<11$ & 16 & $14(25.9)$ & $2(8.3)$ \\
\hline $11-32$ & 58 & $36(66.7)$ & $22(91.7)$ \\
\hline $32-100$ & 4 & $4(7.4)$ & 0 \\
\hline$>100$ & 0 & 0 & 0 \\
\hline
\end{tabular}




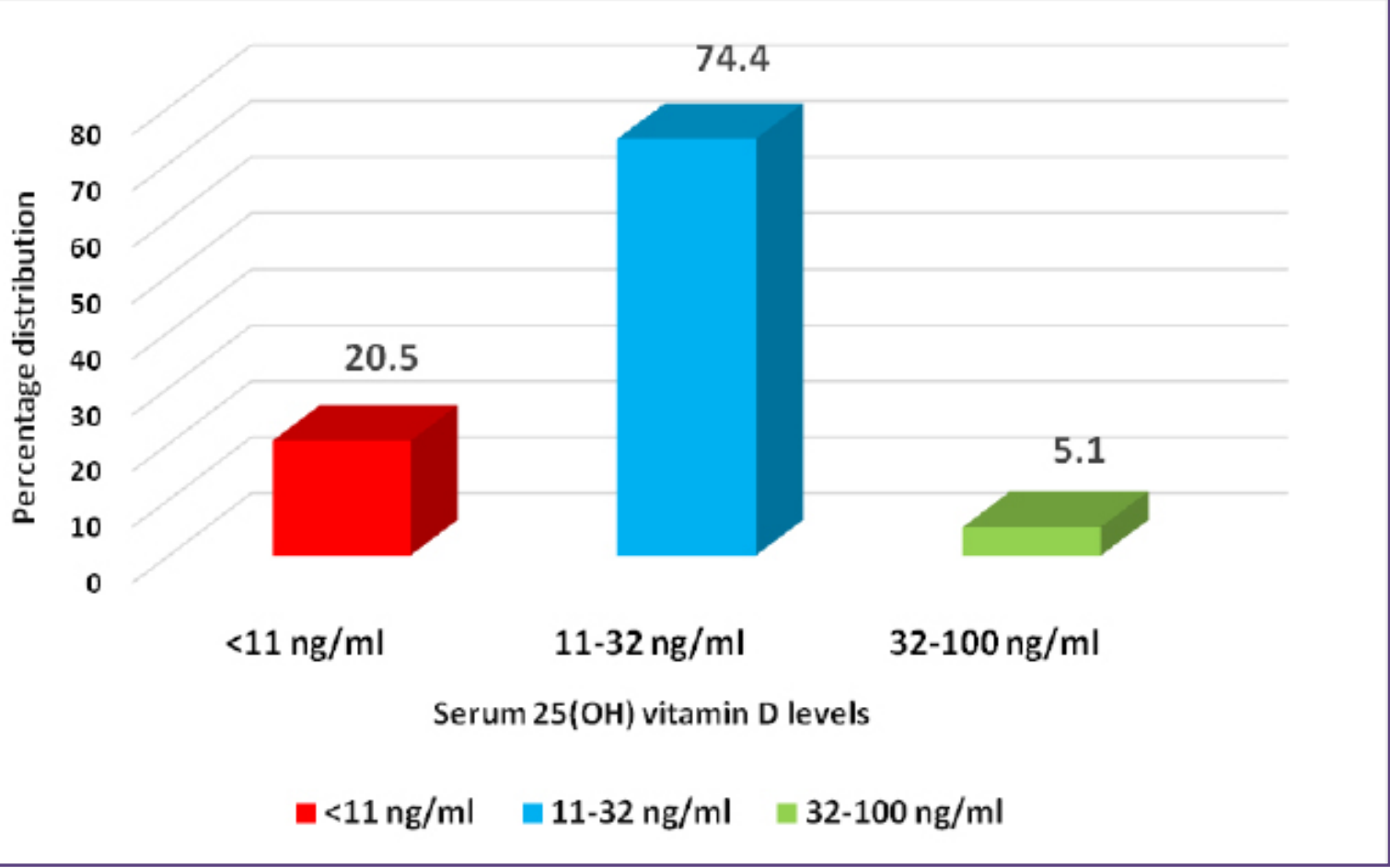

Fig. 1: Distribution of serum 25-(OH)vitamin D levels in antenatal cases $(n=78)$.

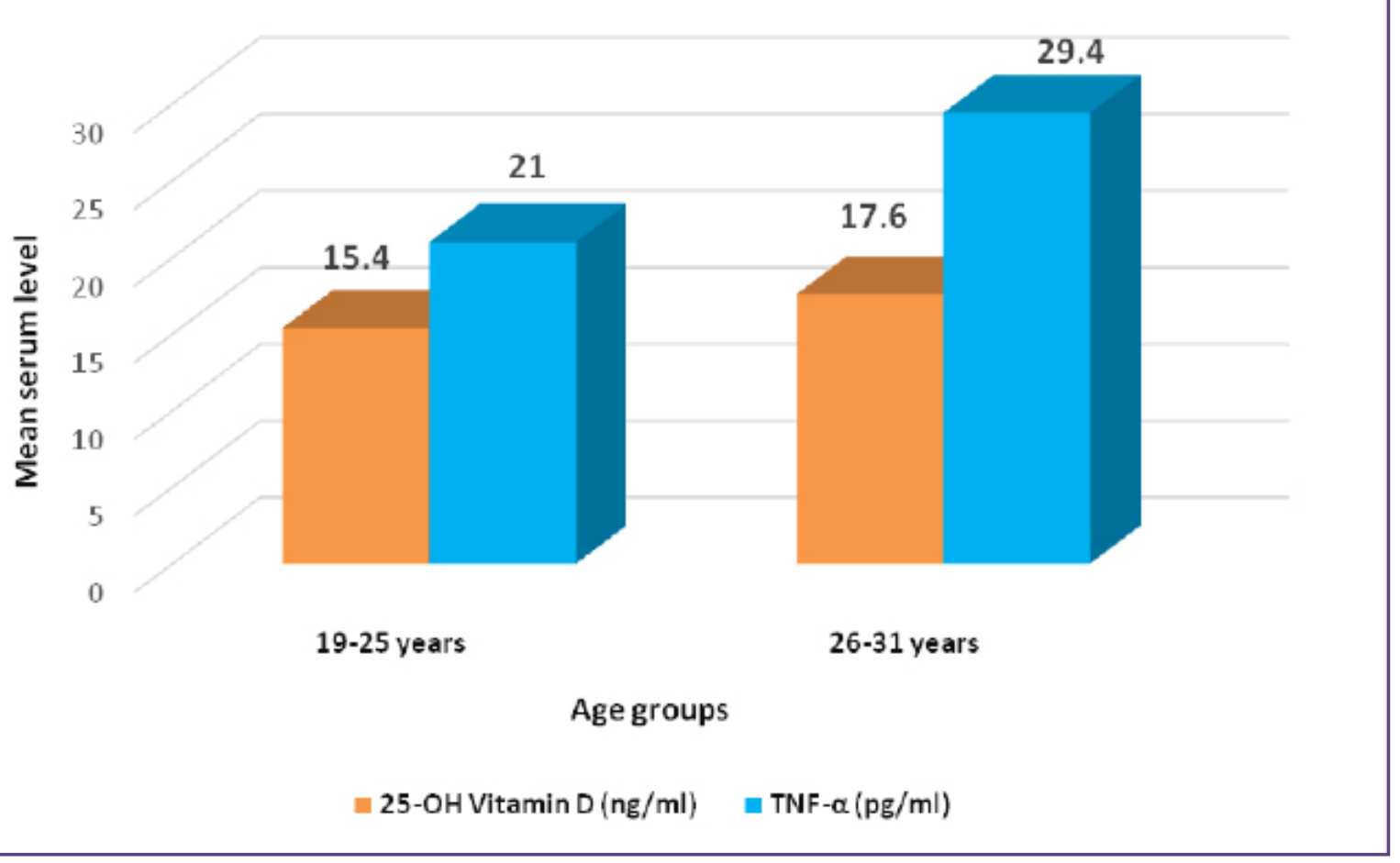

Fig. 2: Age wise distribution of mean serum 25-(OH)vitamin D and TNF- $\alpha$ levels in antenatal cases $(\mathrm{n}=78)$. 


\section{Discussion}

Tuberculosis, a leading infectious disease, is responsible for $16 \%$ of maternal mortality worldwide. 22 India alone accounts for nearly $21 \%$ of global load of TB among antenatal mothers.23 Maternal TB has been associated with various adverse outcomes including enhanced risk of preterm labour and low birth weight babies.24 In India we witness a dual threat of high incidence of TB along with widely prevalent vitamin D deficiency among antenatal mothers. The immunomodulatory and mycobactericidal role of vitamin $\mathrm{D}$ underline the importance of screening for infectious diseases, in particular TB, among antenatal mothers.25 TNF- $\alpha$ plays a key role in the pathogenesis of mycobacterial infection. TNF- $\alpha$, being pivotal in the formation of granulomas for walling off Mycobacterium tuberculosis,. is an important biomarker for the detection of an early tubercular disease. 26

Institute of Medicine (IOM) 2010 Report defined the 25$\mathrm{OH}$ Vitamin D cut off levels as below 12ng/L (30nmol/L) "persons are at risk for bone deficiency" and below 20ng/L (50nmol/L) "Some but not all are potentially at risk".27 The American Congress of Obstetricians \& Gynecologists (ACOG)described the levels below 20ng/L (50nmol/L) as deficiency of $25(\mathrm{OH}) \mathrm{D} .28$ Majority agree that $25-\mathrm{OH}$ Vitamin D levels below $20 \mathrm{ng} / \mathrm{mL}$ signify deficiency of vitamin $\mathrm{D}$. There is no agreement among various studies about the optimal levels of 25-OH Vitamin D especially in antenatal mothers.A National Institute of Child Health and Human Development (NICHD) covered large trial has described vitamin D levels above $32 \mathrm{ng} / \mathrm{ml}$ safe in antenatal mothers.29 Another large trial by Wagner C.L et al. has also supported the levels of $32 \mathrm{ng} / \mathrm{ml}$ as safe levels.30 In line with these findings, we have considered serum $25-\mathrm{OH}$ Vitamin D levels of $<11,11-32$ and 32-100 ng/ml as severe deficiency, insufficiency and adequacy respectively in the present study.

Maternal vitamin D deficiency is associated with suboptimal bone development in foetus. Javaid MK et al. in the longitudinal study have demonstrated a positive association between maternal late pregnancy $25-\mathrm{OH}$ Vitamin D levels and mineral content \& bone density of their offspring at age 9 years as determined by dual energy X-ray absorptiometry (DEXA).31 Same study has reported circulating 25-OH Vitamin D concentrations of 27-50 $\mathrm{nmol} / \mathrm{L}$ in $31 \%$ of the mothers.31 Farrant H.J. et al.in their study based on South Indian mothers have reported vitamin $\mathrm{D}$ deficiency in $66.5 \%$ of pregnant mothers.32 Agarwal $\mathrm{N}$. et al. have documentedvitamin $\mathrm{D}$ deficiency in $75 \%$ of pregnant mothers in Delhi.33 However, present study has demonstratedsevere deficiency of 25-OH Vitamin D in $20.5 \%$ of antenatal mothers. This was probably due to the differences in the cut off values used in these studies to define the vitamin D deficiency. The studies by Farrant H.J. et al. and Agarwal N. et al. have defined Vitamin D deficiency as $25-\mathrm{OH}$ Vitamin $\mathrm{D}<20 \mathrm{ng} / \mathrm{mL}$, whereas in our study we have considered serum 25-OH Vitamin D levels $<11 \mathrm{ng} / \mathrm{mL}$ as severe deficiency.32, 33 The $25-\mathrm{OH}$ Vitamin D levels of $32 \mathrm{ng} / \mathrm{mL}$ or more were seen in $5.1 \%$ antenatal mothers in our study, however another study has reported vitamin D levels of $\geq 30 \mathrm{ng} / \mathrm{mL}$ in $15 \%$ pregnant mothers.33 Marwaha R.K.et al. have observed vitamin $\mathrm{D}$ deficiency in $96.3 \%$ of pregnant mothers.34 Similarly, in present study we have reported low 25-OH Vitamin D levels in $94.9 \%$ antenatal mothers.

The mean25-OH Vitamin D levels in antenatal mothers were $16 \pm 7.5 \mathrm{SD} n g / \mathrm{mL}$ in our study. Our findings are in line with the study by Agarwal N. et al. that has reported $16.24 \pm 4.4 \mathrm{SD} \mathrm{ng} / \mathrm{mL}$ as mean vitamin $\mathrm{D}$ levels in pregnant mothers.33 However, a study by Marwaha R.K.et al. has reported a lower $(9.28 \pm 4.9 \mathrm{SD} \mathrm{ng} / \mathrm{mL})$ mean vitamin $\mathrm{D}$ levels.34 Another study has reported a median vitamin D level of $15.12 \mathrm{ng} / \mathrm{mL}(9.6$ - 23.4) in pregnant mothers.32 Similarly in present study median vitamin D level was $14.5 \mathrm{ng} / \mathrm{ml}$ (3.5-39.5) in antenatal mothers. The present study reported a high proportion of antenatal mothers with low serum 25-OH Vitamin D levels. This emphasizes the urgent need of vitamin D deficiency screening in pregnancy and the follow up supplementation if needed. Despite the paucity of evidence, it is well accepted that vitamin D supplementation or treatment in pregnancy inflict no harm and may prove to be beneficial for maternal and foetal health.

TNF- $\alpha$ is a pro-inflammatory, multifunctional cytokine. TNF- $\alpha$ has been implicated as an inducer of embryopathic stresses and as a triggering agent for immunological pregnancy loss.35, 36 Several researchers have suggested a role of TNF- $\alpha$ in the pathogenesis of preeclampsia.37, 38 A relationship has been proposed between inflammatory processes and preeclampsia.39, 40 This is particularly relevant in developing countries where subclinical, latent, chronic infections are widely prevalent. In present study, mean TNF- $\alpha$ level in antenatal mothers was $24.3 \mathrm{pg} / \mathrm{ml}$. However, another study has reported a higher serum TNF- $\alpha$ level of $51.9 \mathrm{pg} / \mathrm{ml}$ in normal pregnant women. Same study has reported no significant difference in serum TNF- $\alpha$ levels in preeclamptic and normal pregnant mothers $(\mathrm{p}>$ $0.1) .41$ 
Vitamin D is crucial for the proper immune system functioning. It also plays a role in the management of cytokines.42 Cantorna MT et al have demonstrated that vitamin $\mathrm{D}$ stimulates the production of anti-inflammatory cytokines.43 Other studies have documented that vitamin $\mathrm{D}$ down-regulates the production of pro-inflammatory cytokines including TNF- $\alpha .44,45$ However in present study, no correlation was present between serum vitamin $\mathrm{D}$ and TNF- $\alpha$ levels in antenatal mothers. Our findings are in agreement with another study that has reported no significant correlations between serum vitamin $\mathrm{D}$ and TNF- $\alpha$ levels in healthy women.46

We recognize that present study has many limitations. Our study focused on serum vitamin D and TNF-alevels in apparently healthy antenatal mothers. Similar studies involving larger number of subjects with inflammatory or chronic conditions would be very useful. Vitamin D deficiency is highly prevalent in developing countries, and recent researches support its importance in various diseases. Cytokines plays a key role in immune regulation, therefore further studies involving both healthy and diseased populations are required to elaborate on relationship between vitamin $\mathrm{D}$ and various cytokine levels.

\section{Conclusion}

Vitamin D deficiency adversely affects not only the health of pregnant mother but also her child. In our setting where subnormal vitamin D levels are prevalent in antenatal mothers, screening for vitamin D deficiency in early pregnancy with subsequent supplementation if needed is recommended. No correlation was observed between serum vitamin $\mathrm{D}$ and pro-inflammatory marker TNF- $\alpha$ levels in antenatal mothers. However, epidemiological studies on larger scale could be initiated for screening of levels of such cytokines along with few other key biomarkers with varying levels of vitamin D in antenatal mothers, in order to better manage and contain these infections. Further studies are required to investigate the effects of vitamin D on cytokine environment especially in pregnant mothers. Moreover, the outcomes of vitamin D supplementation in pregnancy on maternal and child health need to be thoroughly investigated.

\section{Compliance with Ethical Standards}

Conflict of interest Author Bineeta Kashyap declares that she has no conflict of interest. Author Nisha Goyal declares that she has no conflict of interest. Author Neha Gupta declares that he has no conflict of interest. Author SapnaJhanjhria declares that she has no conflict of interest.

Ethical Approval This study was conducted with sera that had already been receivedin routine for Venereal Disease
Research Laboratory (VDRL) testing in antenatal mothers. No additional sample was taken particularly for this study.

Informed ConsentInformed consent was obtained from all individual participants included in the study.

\section{References}

1. Mithal A, Wahl DA, Bonjour JP, Burckhardt P, DawsonHughes B, Eisman JA, et al. Global vitamin D status and determinants of hypovitaminosis D. Osteoporos Int. 2009;20:1807-1820.

2. Sahu M, Bhatia V, Aggarwal A, Rawat V, Saxena P, Pandey A, et al. Vitamin D deficiency in rural girls and pregnant women despite abundant sunshine in northern India. ClinEndocrinol (Oxf). 2009;70:680-684.

3. Dasgupta A, Saikia U, Sarma D. Status of 25(OH)D levels in pregnancy: A study from the North Eastern part of India. Indian J EndocrinolMetab. 2012;16:S405-407.

4. Specker BL. Does vitamin D during pregnancy impact offspring growth and bone? Proc Nutr Soc. 2012;71:38-45.

5. Ota K, Dambaeva S, Han AR, Beaman K, Gilman-Sachs A, Kwak-Kim J. Vitamin D deficiency may be a risk factor for recurrent pregnancy losses by increasing cellular immunity and autoimmunity. Hum Reprod. 2014;29:208-219.

6. BodnarLM, KlebanoffMA, GernandAD, PlattRW, Parks WT, Catov JM, et al. Maternal vitamin D status and spontaneous preterm birth by placental histology in the US Collaborative Perinatal Project. Am J Epidemiol. 2014;179:168-176.

7. Hyppönen E, Cavadino A, Williams D, Fraser A, Vereczkey A, Fraser WD, et al. Vitamin D and pre-eclampsia: Original data, systematic review and meta-analysis. Ann NutrMetab. 2013;63:331-340.

8. Lacroix M, Battista MC, Doyon M, Houde G, Ménard J, Ardilouze JL, et al. Lower vitamin D levels at first trimester are associated with higher risk of developing gestational diabetes mellitus. ActaDiabetol. 2014;51:609-616.

9. Bowyer L, Catling-Paull C, Diamond T, Homer C, Davis G, Craig ME. Vitamin D, PTH and calcium levels in pregnant women and their neonates. ClinEndocrinol (Oxf).2009;70:372-377.

10. Mehrotra P, Marwaha RK, Aneja S, Seth A, Singla BM, Ashraf G, et al. Hypovitaminosis D and hypocalcemic seizures in infancy. Indian Pediatr. 2010;47:581-586.

11. Royal College of Obstetricians and Gynaecologists. Vitamin $\mathrm{D}$ in Pregnancy. Scientific Impact Paper:43. Available from: https://www.rcog.org.uk/globalassets/documents/ guidelines/scientific-impact-papers/vitamin_d_sip43 june14.pdf(accessed 07 September 2018)

12. Yildirim I, Magden K, Hur E. Infection Inflammation and Vitamin D. Clin Microbial. 2013; 2: 116.

13. Camargo CA Jr, Rifas-Shiman SL, Litonjua AA, RichEdwards JW, Weiss ST, Gold DR, et al. Maternal intake of vitamin D during pregnancy and risk of recurrent wheeze in children at 3 y of age. Am J ClinNutr. 2007;85:788-795. 
14. Barnes PF, Lu S, Abrams JS, Wang E, Yamamura M, Modlin RL. Cytokine production at the site of disease in human tuberculosis. Infect Immun. 1993 Aug;61:3482-3489.

15. Ladel CH, Szalay G, Riedel D, Kaufmann SH. Interleukin-12 secretion by Mycobacterium tuberculosis-infected macrophages. Infect Immun. 1997;65:1936-1938.

16. Serbina NV, Flynn JL. Early Emergence of CD8+ T Cells Primed for Production of Type 1 Cytokines in the Lungs of Mycobacterium tuberculosis-Infected Mice. Kaufmann SHE, ed. Infect Immun. 1999;67:3980-3988.

17. Yu K, Mitchell C, Xing Y, Magliozzo RS, Bloom BR, Chan J. Toxicity of nitrogen oxides and related oxidants on mycobacteria: M. tuberculosis is resistant to peroxynitrite anion. Tuber Lung Dis. 1999;79(4):191-198.

18. Scanga CA, Mohan VP, Yu K, et al. Depletion of Cd4+ T Cells Causes Reactivation of Murine Persistent Tuberculosis despite Continued Expression of Interferon $\gamma$ and Nitric Oxide Synthase 2. J Exp Med. 2000;192:347-358.

19. Vital Reyes VS, Téllez Velasco S, Hinojosa Cruz JC, Ortiz Romero Mde J, ChavarríaOlarte ME, Reyes Fuentes A. Serum levels of IL-1beta, IL-6 and TNF-alpha in infertile patients with ovarian dysfunction. GynecolObstet Mex. 2005;73:604-610.

20. El-Far M, El-Sayed IH, El-Motwally AE, Hashem IA, Bakry N. Serum levels of TNF-alpha and antioxidant enzymes and placental TNF-alpha expression in unexplained recurrent spontaneous miscarriage. J PhysiolBiochem. 2009;65:175181.

21. Hollis BW, Wagner CL. Vitamin D deficiency during pregnancy: an ongoing epidemic. Am J Clin Nutr. 2006; $84: 273$.

22. Say L, Chou D, Gemmill A, Tunçalp Ö, Moller AB, Daniels J,et al. Global causes of maternal death: a WHO systematic analysis. Lancet Glob Health. 2014;2(6):e323-e333.

23. Sugarman J, Colvin C, Moran AC, Oxlade O. Tuberculosis in pregnancy: an estimate of the global burden of disease. Lancet Glob Health. 2014;2(12):e710-e716.

24. Mathad JS, Gupta A. Tuberculosis in pregnant and postpartum women: epidemiology, management, and research gaps. Clin Infect Dis. 2012;55:1532-1549.

25. Martineau AR, Wilkinson KA, Newton SM, Floto RA, Norman AW, Skolimowska K, et al. IFN-gamma- and TNFindependent vitamin D-inducible human suppression of mycobacteria: the role of cathelicidin LL-37. J Immunol. 2007 Jun 1;178(11):7190-8. Erratum in: J Immunol. 2007;179(12):8569-8570.

26. Kindler V, Sappino AP, Grau GE, Piguet PF, Vassalli P. The inducing role of tumor necrosis factor in the development of bactericidal granulomas during BCG infection. Cell. 1989;56(5):731-740.

27. Institute of Medicine (US) Committee to Review Dietary Reference Intakes for Vitamin D and Calcium; Ross AC, Taylor CL, Yaktine AL, Valle HBD, editors. Dietary
Reference Intakes for Calcium and Vitamin D. Washington (DC): National Academies Press (US); 2011. Available from: https://www.ncbi.nlm.nih.gov/books/NBK56070/ doi: $10.17226 / 13050$

28. ACOG Committee on Obstetric Practice. ACOG Committee Opinion No. 495: Vitamin D: Screening and supplementation during pregnancy. Obstet Gynecol. 2011;118:197-198.

29. Hollis BW, Johnson D, Hulsey TC, Ebeling M, Wagner CL. Vitamin D supplementation during pregnancy: double-blind, randomized clinical trial of safety and effectiveness. J Bone Miner Res. 2011 Oct;26:2341-2357.

30. Wagner CL, McNeil R, Hamilton SA, Winkler J, Rodriguez Cook C, Warner G, Bivens B, Davis DJ, Smith PG, Murphy M, Shary JR, Hollis BW. A randomized trial of vitamin D supplementation in 2 community health center networks in South Carolina. Am J Obstet Gynecol. 2013 Feb;208:137. e1-13.

31. Javaid MK, Crozier SR, Harvey NC, Gale CR, Dennison EM, Boucher BJ, et al. Maternal vitamin D status during pregnancy and childhood bone mass at age 9 years: a longitudinal study. Lancet.2006;367:36-43.

32. Farrant HJ, Krishnaveni GV, Hill JC, Boucher BJ, Fisher DJ, Noonan K, Osmond C, Veena SR, Fall CH. Vitamin $\mathrm{D}$ insufficiency is common in Indian mothers but is not associated with gestational diabetes or variation in newborn size. Eur J ClinNutr. 2009 May;63:646-652.

33. Agarwal N, Arya SC. Vitamin D3 Levels in Pregnant Women and Newborns at a Private Tertiary Care Hospital in Delhi, India. Int J Gynecol Obstet. 2011; 113, 240-241.

34. Marwaha RK, Tandon N, Chopra S, Agarwal N, Garg MK, Sharma B, Kanwar RS, Bhadra K, Singh S, Mani K, Puri S. Vitamin D status in pregnant Indian women across trimesters and different seasons and its correlation with neonatal serum 25-hydroxyvitamin D levels. Br J Nutr. 2011;106:13831389.

35. Clark DA, Arck PC, Chaouat G. Why did your mother reject you? Immunogenetic determinants of the response to environmental selective pressure expressed at the uterine level. Am J ReprodImmunol. 1999;41:5-22.

36. Raghupathy R. Pregnancy: Success and failure within the Th1/Th2/Th3 paradigm. SeminImmunol. 2001;13:219-227

37. Kupferminc MJ, Peaceman AM, Aderka D, Wallach D, Socol ML. Soluble tumor necrosis factor receptors and interleukin-6 levels in patients with severe preeclampsia. Obstet Gynecol.1996; 88:420-427.

38. Teran E, Escudero C, Moya W, Flores M, Vallance P, Lopez-Jaramillo P. Elevated C-reactive protein and proinflammatorycytokines in Andean women with preeclampsia. Int J Gynecol Obstet.2001; 75:243-249.

39. Hill JA, Devoe LD, Bryans CI Jr. Frequency of asymptomatic bacteriuria in preeclampsia. Obstel Gynecol.1986, 67:529532.

40. Hsu CD, Witter FR. Urogenital infection in preeclampsia. Int J GynecolObstel.1995; 49:271-275. 
41. Afshari JT, Ghomian N, ShameliA, Shakeri MT, Fahmidehkar MA, Mahajer E, et al. Determination of Interleukin-6 and Tumor Necrosis Factor-alpha concentrations in IranianKhorasanian patients with preeclampsia. BMC Pregnancy Childbirth. 2005 Nov 1;5:14.

42. van Etten E, Mathieu C. Immunoregulation by 1,25-dihydroxyvitamin D3: basic concepts. J Steroid BiochemMol Biol. 2005;97:93-101.

43. Cantorna MT, Woodward WD, Hayes CE, DeLuca HF. 1,25-dihydroxyvitamin D3 is a positive regulator for the two anti-encephalitogenic cytokines TGF-beta 1 and IL-4. J Immunol. 1998;160:5314-5319.

44. Zhu Y, Mahon BD, Froicu M, Cantorna MT. Calcium and 1 alpha, 25-dihydroxyvitamin D3 target the TNF-alpha pathway to suppress experimental inflammatory bowel disease. Eur J Immunol. 2005;35:217-224.

45. Lemire JM. Immunomodulatory role of 1 , 25-dihydroxyvitamin D3. J Cell Biochem. 1992;49:26-31.

46. Azizieh F, Alyahya KO, Raghupathy R. Association between levels of vitamin D and inflammatory markers in healthy women. J Inflamm Res. 2016;9:51-57.

*Corresponding author:

Dr. Bineeta Kashyap, Flat no. C-402, Vimal CGHS LTD., Plot-3, Sector-12, Dwarka, New Delhi-78

Email: dr_bineetakashyap@yahoo.co.in

Financial or other Competing Interests: None. 